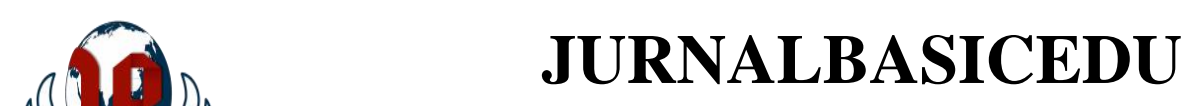

Volume 5 Nomor 5Tahun 2021 Halaman 3196 - 3202

Research \&Learningin Elementary Education https://jbasic.org/index.php/basicedu

PAHLAWAN

\title{
Pengaruh Penggunaan Media Wayang Kardus terhadap Kemampuan Bercerita Peserta Didik di Sekolah Dasar
}

\author{
Islahatul Muthohharoh ${ }^{1 凶}$, Syamsul Ghufron $^{2}$, Nafiah $^{3}$, Sri Hartatik ${ }^{4}$ \\ Universitas Nahdlatul Ulama Surabaya, Indonesia ${ }^{1,2,3,4}$ \\ E-mail: islahatulmuthohharoh092.sd17@student.unusa.ac.id ${ }^{1}$, syamsulghufron@unusa.ac.id ${ }^{2}$, nefi_23@unusa.ac.id ${ }^{3}$, \\ titax@unusa.ac.id ${ }^{4}$
}

\begin{abstract}
Abstrak
Penelitian ini bertujuan untuk mengetahui kemampuan bercerita peserta didik setelah menggunakan media wayang kardus dalam proses pembelajaran bercerita. Pendekatan yang digunakan dalam penelitian ini adalah pendekatan kuantitatif, penelitian ini menggunakan Experimental Research dengan desain One Grup Pretest-Posttest Design. Populasi dan sampelnya adalah peserta didik kelas II UPT SDN 106 Gresik dengan jumlah sampel 22 peserta didik. Pengambilan sampel menggunakan teknik sampel jenuh dan pengumpulan data menggunakan tes performansi berupa pretest-posttest. Adapun uji data dianalisis menggunakan uji Shapiro wilk, dari data hasil kemampuan bercerita peserta didik berdistribusi normal dan homogen diuji menggunakan uji t-test. Hasil penelitian menunjukkan bahwa: (1) Kemampuan bercerita peserta didik pada kelas II UPT SDN 106 Gresik sebelum menggunakan media wayang kardus dalam proses pembelajaran bercerita memperoleh nilai rata-rata 67.82. (2) Kemampuan bercerita peserta didik pada kelas II UPT SDN 106 Gresik setelah menggunakan media wayang kardus dalam proses pembelajaran bercerita memperoleh nilai rata-rata 83.59. (3) Terdapat perbedaan hasil kemampuan bercerita pada peserta didik kelas II UPT SDN 106 Gresik sebelum dan sesudah menggunakan media wayang kardus dapat dilihat mengalami peningkatan dengan taraf signifikan $0.00<0.05$.
\end{abstract}

Kata Kunci: Media wayang kardus, Kemampuan bercerita.

\begin{abstract}
This study aims to determine the storytelling ability of students after using the cardboard puppet media in the storytelling learning process. The approach used in this study is a quantitative approach, this study uses Experimental Research with One Group Pretest-Posttest Design. The population and the sample are students of class II UPT SDN 106 Gresik with a total sample of 22 students. Sampling using saturated sampling technique and data collection using performance tests in the form of pretest-posttest. The test data were analyzed using the Shapiro Wilk test, from the data from the results of the students' storytelling abilities that were normally distributed and homogeneous were tested using the t-test. The results showed that: (1) The storytelling ability of students in class II UPT SDN 106 Gresik before using the cardboard puppet media in the storytelling learning process obtained an average score of 67.82. (2) The storytelling ability of students in class II UPT SDN 106 Gresik after using the cardboard puppet media in the storytelling learning process obtained an average score of 83.59. (3) There is a difference in the results of the storytelling ability of the second grade students of UPT SDN 106 Gresik before and after using the cardboard puppet media, which can be seen to have increased with a significant level of $0.00<0.05$.
\end{abstract}

Keywords: Cardboard puppet media, Storytelling ability.

Copyright (c) 2021 Islahatul Muthohharoh, Syamsul Ghufron, Nafiah, Sri Hartatik

$\triangle$ Corresponding author :

Email : islahatulmuthohharoh092.sd17@student.unusa.ac.id

ISSN 2580-3735 (Media Cetak)

DOI : https://doi.org/10.31004/basicedu.v5i5.1267

ISSN 2580-1147 (Media Online) 
3197 Pengaruh Penggunaan Media Wayang Kardus terhadap Kemampuan Bercerita Peserta Didik di Sekolah Dasar - Islahatul Muthohharoh, Syamsul Ghufron, Nafiah, Sri Hartatik

DOI: https://doi.org/10.31004/basicedu.v5i5.1267

\section{PENDAHULUAN}

Pendidikan merupakan salah satu upaya yang bertujuan untuk meningkatkan mutu sumber daya manusia. Pendidikan mempunyai arti sebagai usaha sadar manusia yang sudah terencana untuk meningkatkan proses belajar mengajar sepanjang hayat, meliputi semua sendi kehidupan, seluruh lapisan masyarakat dari segala usia (Khair, 2018). Cara belajar peserta didik di Sekolah diarahkan dan tidak dibiarkan tanpa memiliki tujuan, peserta tetap diberi kesempatan memilih pembelajaran yang diminati dan tidak memaksakan tapi pembelajaran tetap diarahkan oleh pendidik (Fatria \& Husna, 2019). Bercerita mempunyai tujuan untuk menumbuhkan tentang sikap keberanian, keramahan, kecakapan dalam menyampaikan pendapat dan membantu mengembangkan karakteristik dalam diri perta didik (Thirsa Laules Purwa, 2019). Keterampilan bercerita merupakan sebuah kemampuan untuk menyampaikan informasi kepada pendengar, dalam metode bercerita ada beberapa hal yang perlu diperhatikan yaitu kesesuaian topik, ketepatan urutan dalam cerita, kelancaran bercerita dan ketepatan dalam intonasi (Annafiah, 2017). Aktivitas belajar mengajar perlu ditunjang dengan berbantu media pembelajaran agar pembelajaran berjalan dengan sesuai yang diharapkan. Media wayang kardus adalah media yang digunakan sebagai alat peraga untuk bercerita agar pesan dapat tersampaikan kepada peserta didik karena dapat menarik perhatian siswa serta wayang kardus juga merupakan alat peraga yang dengan mudah dapat menarik perhatian peserta didik (Rukayah, 2015). Menurut Ismiulya (2019: 17) media pembelajaran adalah suatu alat bantu atau perantara berfungsi untuk memudahkan guru dalam menyampaikan informasi kepada peserta didik. Selain itu, media pembelajaran menurut Suciati \& Fatimah (2018), berfungsi untuk menumbuhkan motivasi dan minat belajar peserta didik, Media wayang kardus tersebut menjadi suatu alternatif untuk dapat memudahkan peserta didik dalam pembelajaran bercerita serta menunjang keberhasilan tujuan pembelajaran, dan pembelajaran lebih menyenangkan sehingga peserta didik menjadi lebih aktif. Hal ini sesuai dengan pendapat (Irfan, 2017). Pendapat tersebut juga didukung oleh Subekti (2016: 18), yang menjabarkan bahwa media mempelajaran merupakan alat yang mampu membantu proses pembelajaran yang berfungsi untuk memperjelas makna pesan yang ingin disampaikan selain itu media wayang kardus juga bisa menjadi sarana pembelajaran bercerita tentang seorang tokoh dengan keunggulan nilai yang dimiliki sang tokoh tersebut (Andajani, 2008).

Berdasarkan kegiatan wawancara yang telah dilakukan oleh peneliti kepada guru kelas pada bulan November 2020 mendapatkan informasi tentang permasalah yang dialami ketika proses pembelajaran dan peneliti merumuskan beberapa masalah yaitu (1) peserta didik terlihat malu-malu dan grogi ketika bercerita didepan teman-temannya (2) kurangnya media dalam proses pembelajaran bercerita sehingga membuat peserta didik kurang memahami isi cerita dan tidak paham alur cerita yang disampaikan oleh pendidik (3) kemampuan bercerita peserta didik masih tergolong rendah. Tujuan penelitian ini untuk mengetahui adakah pengaruh penggunaan media wayang kardus terhadap kemampuan bercerita peserta didik kelas II di UPT SDN 106 Gresik.

Media pembelajaran digunakan untuk membuat peserta didik tertarik untuk mengikuti pembelajaran dan diharapkan pembelajaran dapat terlaksana secara efektif. Pendapat menurut Sujibto (2013: 8), Pendapat tersebut juga didukung oleh Subekti (2016: 18), yang menjabarkan bahwa media mempelajaran merupakan alat yang mampu membantu proses pembelajaran yang berfungsi untuk memperjelas makna pesan yang ingin disampaikan sehingga dapat mencapai tujuan pembelajaran yang diharapkan. Beberapa manfaat dari media pembelajaran menurut Ramli (2018) menghadirkan media dalam proses pembelajaran:

1) Menumbuhkan minat semangat belajar.

2) Mencapai sasaran yang lebih baik dan tepat.

3) Membantu mengatasi hambatan pemahaman.

4) Memberi stimulus kepada peserta didik untuk menyampaikan pesan-pesan.

5) Merangsang sasaran pendidikan untuk meneruskan pesan-pesan yang diterima kepada orang lain. 
3198 Pengaruh Penggunaan Media Wayang Kardus terhadap Kemampuan Bercerita Peserta Didik di Sekolah Dasar - Islahatul Muthohharoh, Syamsul Ghufron, Nafiah, Sri Hartatik

DOI: https://doi.org/10.31004/basicedu.v5i5.1267

6) Mempermudah penyampaian materi pembelajaran oleh pendidik atau guru.

7) Mempermudah penerimaan informasi oleh sasaran pendidikan.

8) Mendorong keinginin orang untuk ingin mengetahui dan lebih mendalami suatu hal serta memberikan persepsi yang lebih baik.

Membantu mengingat kembali pemahaman suatu hal yang pernah diperoleh. Manusia mempunyai kecenderungan lebih mudah lupa di dalam menerima sesuatu hal yang baru. Menggunakan kardus sebagai bahan utama untuk pembuatan wayang mudah didapatkan, juga tidak membutuhkan banyak biaya dan pembuatannya juga mudah, ramah lingkungan dan juga tidak berbahaya bagi anak-anak. Bahan yang digunakan bisa dari kardus bekas sembako atau membelinya karena harga kardus bekas tidak begitu mahal. Semua tak lepas dari kreativitas seorang guru atau pendidik dalam proses pembuatan dan penggunaan media pembelajaran wayang kardus (Wijayak \& Wismanto, 2020: 117). Media wayang merupakan salah satu media pembelajaran yang menarik. Guru menggunakan media wayang kardus untuk menyampaikan materi bercerita yang terbuat dari kardus ada gambarnya dan diberi tangkai untuk menggerak-gerakkannya Suwarna (dalam Amalia \& Sulistyowati 2020)

Kemampuan bercerita adalah salah satu jenis kemampuan yang penting untuk melatih komunikasi. Menurut Agus dalam Sanura (2018: 34), menjelaskan bahwa manfaat kegiatan bercerita ada lima, yaitu yang pertama, mengembangkan daya imajinasi dan kreativitas bahwa peserta didik membutuhkan penyaluran imajinasi dan fantasi tentang berbagai hal yang selalu muncul dalam pikiran peserta didik, salah satu tempat yang tepat untuk menyalurkan imajinasi peserta didik adalah dengan bercerita. Manfaat yang kedua adalah meningkatkan kemampuan berpikir, melatih peserta didik untuk mengolah kata menggunakan bahasanya menambah wawasan kosa kata peserta didik serta membebaskan peserta didik berpikir sesuai imajinasinya dan guru harus mampu mengarahkan agar peserta didik mengikuti pembelajaran dengan menyenangkan (Rachmi, 2015). Manfaat yang ketiga yaitu menjalin interaksi dan berkomunikasi, untuk lebih memberikan kesempatan kepada peserta didik untuk meningkatkan aktivitas peserta didik agar merasa benar-benar ikut ambil bagian dan berperan aktif dalam proses belajar mengajar dan memberi kesempatan kepada peserta didik untuk berkomunikasi menyampaikan maksud maupun perasaannya (Dewi \& Wiyasa, 2018). Manfaat yang keempat melatih percaya diri, ketika peserta didik sering dilatih untuk tampil kedepan kelas dihadapan temantemannya hal tersebut akan melatih kepercayaan peserta didik untuk berani maju dan menyampaikan pendapatnya. Manfaat yang kelima melatih konsentrasi, peserta didik mampu lebih berkonsentrasi dan memahami isi alur dari cerita tersebut, sehingga peserta didik mampu menceritakan kembali isi cerita tanpa harus menghafalkan setiap kata, karena mereka fokus jadi mereka akan mudah paham.

Penelitian yang berjudul "Pengaruh Penggunaan Media Wayang Kardus terhadap Kemampuan Bercerita Peserta Didik di UPT SDN 106 Gresik" ini relevan dengan beberapa penelitian yang terkait dengan penggunaan media wayang kardus dan kemampuan bercerita. Adapun penelitan yang dimaksud diantaranya adalah penelitian Yanti (2019) berjudul "Penelitian Penerapan Metode Bercerita dan Media Wayang Kardus Untuk Meningkatkan Motivasi Belajar dalam Pembelajaran Aqidah akhlak pada Siswa Kelas IV Madrasah Ibtidaiyah Nurul Ittihad", Ismiulya (2019) melakukan penelitian dengan judul "Penerapan Metode Bercerita Menggunakan Media Wayang Kardus Untuk Meningkatkan Pemahaman Konsep Huruf Pada anak Usia 5-6 Tahun di TKIT Cendikia Darussalam Aceh Besar", Lauroza \& Hartati (2019) yang berjudul "Pengaruh Media Gambar Terhadap Kemampuan Bercerita Anak di TK Islam Daud Kholifahtulloh Tabing Padang”. Bertujuan untuk mengetahui pengaruh media gambar terhadap kemampuan bercerita peserta didik.Sari (2017) melakukan penelitian dengan judul "Pengaruh Media Wayang Kardus Terhadap Hasil Belajar Mengidentifikasi Unsur Cerita Siswa Kelas V SDN Pandeanlamper 03 Semarang". Tujuan dari penelitian ini adalah untuk merangsang aktivitas dan pola pikir siswa dalam belajar agar lebih aktif dan kreatif dapat membantu siswa mencapai tujuan pembelajaran. 
3199 Pengaruh Penggunaan Media Wayang Kardus terhadap Kemampuan Bercerita Peserta Didik di Sekolah Dasar - Islahatul Muthohharoh, Syamsul Ghufron, Nafiah, Sri Hartatik

DOI: https://doi.org/10.31004/basicedu.v5i5.1267

\section{METODE PENELITIAN}

Dalam penelitian ini yang digunakan adalah pendekatan kuantitatif. Tahapan pelaksanaan pada penelitian ini ada tiga, tahapan pertama adalah melakukan pretest. Dalam pretest peserta didik diminta untuk menceritakan secara lisan. Pretest ini bertujuan untuk mengetahui kemampuan awal bercerita peserta didik sebelum diberikan perlakuan (treatment). Tahap kedua treatment, yang diberikan dalam bentuk penyampaian cerita oleh pendidik dengan menggunakan media wayang kardus. Tahapan ketiga adalah Posttest. Pada saat posttest peserta didik juga diminta untuk bercerita secara lisan menggunakan media wayang kardus. Posttest ini bertujuan untuk mengetahui kemampuan bercerita peserta didik setelah diberikan perlakuan (treatment). Penelitian ini dilakukan di UPT SDN 106 Gresik yang terletak di Dusun Kricak, Desa Karangan Kidul, Kecamatan Benjeng, Kabupaten Gresik. Penelitian ini berlangsung dilakukan selama 2 hari pada bulan juni 2021. Populasi dalam penelitian ini adalah 22 peserta didik kelas II di UPT SDN 106 Gresik tahun pelajaran 2020-2021 yang terdiri dari 6 perempuan dan 16 laki-laki. Sampel adalah kelompok kecil secara nyata yang memiliki karakteristik yang dijadikan dasar dalam penentuan kesimpulan (Sukmadinanta, 2012). Sampel adalah sebagian objek dari populasi dijadikan sebagai penelitian (Darmadi, 2011). Teknik pengambilan sampel dalam penelitian ini adalah sampel jenuh. Sampel jenuh adalah teknik penentuan sampel apabila semua anggota populasi digunakan sebagai sampel, hal ini sering dilakukan bila jumlah populasi relatif kecil (Sugiyono, 2018). Teknik pengumpulan data menggunakan teknik tes performansi pretest-postest,tes performansi adalah tes yang cara penilaian yang menganjurkan peserta didik melakukan kegiatan dalam bentuk perbuatan atau tindakan yang diamati guru atau peneliti (Asrul \& Rusydi Ananda, 2014). Teknik Analisis Data menggunakan uji prasyarat yaitu uji normalitas, uji homogenitas, dan uji hipotesis menggunakan One-sampel test (uji-t).

\section{HASIL DAN PEMBAHASAN}

Tabel 1. Uji Normalitas

\begin{tabular}{lrcr}
\hline \multicolumn{4}{c}{ Tests of Normality } \\
\hline & \multicolumn{4}{c}{ Shapiro-Wilk } \\
\cline { 2 - 4 } & Statistic & Df & Sig. \\
\hline Pree & .938 & 22 & .180 \\
\hline Post & .918 & 22 & .069 \\
\hline
\end{tabular}

Berdasarkan tabel diatas menggunakan Shapiro-Wilk diperoleh nilai sig. Pretest sebesar 0,180 dan Postest sebesar 0,069 apabila nilai signifikan $\geq 0,05$ maka data berdistribusi normal. Hal ini berarti data penelitian dinyatakan berdistribusi normal.

Tabel 2. Uji Homogenitas

Test of Homogeneity of Variances

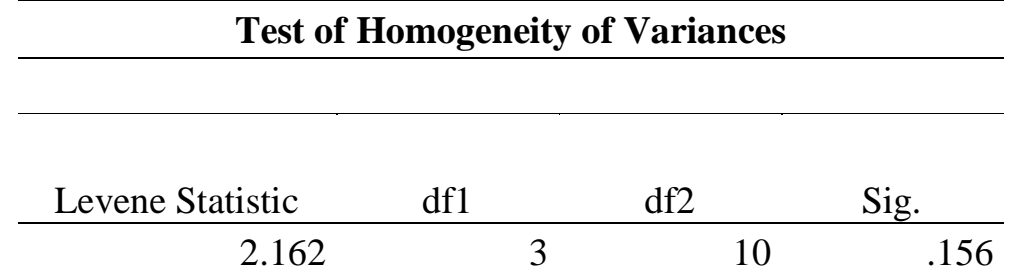

Berdasarkan hasil perhitungan dan pengolahan data yang dilakukan dengan SPSS versi 22, diperoleh niai signifikan $0,156>0,05$, dapat disimpulkan bahwa pretest-postest yaitu sampel pembanding yang pembelajaran dengan tanpa menggunakan media dan sampel yang pembelajarannya menggunakan media wayang kardus memiliki varian yang sama atau homogen. 
Tabel 3. Uji Hipotesis Uji One-Sampel Test (Uji T)

\begin{tabular}{|c|c|c|c|c|c|c|}
\hline \multicolumn{7}{|c|}{ One-Sample Test } \\
\hline & \multicolumn{6}{|c|}{ Test Value $=0$} \\
\hline & \multirow[b]{2}{*}{$\mathrm{T}$} & \multirow[b]{2}{*}{$\mathrm{Df}$} & \multirow[b]{2}{*}{ Sig. (2-tailed) } & \multirow{2}{*}{$\begin{array}{c}\text { Mean } \\
\text { Difference }\end{array}$} & \multicolumn{2}{|c|}{$\begin{array}{l}\text { 95\% Confidence Interval of the } \\
\text { Difference }\end{array}$} \\
\hline & & & & & Lower & Upper \\
\hline Pree & 40.692 & 21 & .000 & 67.818 & 64.35 & 71.28 \\
\hline Post & 56.332 & 21 & .000 & 83.591 & 80.50 & 86.68 \\
\hline
\end{tabular}

Dari tabel di atas, hasil analisis data diketahui bahwa nilai signifikan sebesar 0,000 lebih kecil dari signifikansi $0,05(0,000<0,05)$, maka hipotesis $\left(H_{1}\right)$ dalam penelitian ini dinyatakan diterima. Artinya, terdapat pengaruh yang signifikan antara kemampuan bercerita peserta didik sebelum menggunakan media dengan sesudah menggunakan media wayang kardus pada peserta didik kelas II UPT SDN 106 Gresik.

Hasil penelitian dengan menggunakan media wayang kardus untuk pembelajaran bercerita menunjukkan sebuah keberhasilan dalam peningkatan kemampuan bercerita, karena peserta didik banyak yang lebih semangat ketika menggunakan media wayang kardus, peserta didik merasa tertarik mengikuti pembelajaran dan tidak malu-malu serta grogi lagi dalam bercerita maju ke depan kelas.

Berdasarkan penyajian data diatas hasil penelitian dapat diuraikan secara rinci tentang pengaruh penggunaan media wayang kardus terhadap kemampuan bercerita peserta didik kelas II di UPT SDN 106 Gresik. Hasil pada nilai pretest menunjukkan kemampuan bercerita peserta didik kurang dari KKM (70) yaitu mendapatkan nilai rata-rata 67,818 sedangkan pada nilai posttest mengalami peningkatan yang signifikan yaitu nilai rata-rata 83,591 . Sejalan dengan penelitian Irfan yang berpendapat pentingnya sebuah media pembelajaran karena meskipun siswa masih memiliki kendala pada aspek tata bahasa, penggunaan kosa kata yang belum variatif namun penguasaan tema kelancaran dan ketenangan dalam bercerita menunjukkan hasil yang cukup memuaskan (Irfan, 2017). Pada kegiatan pembelajaran bercerita sebelum menggunakan media wayang kardus (pretest) peserta didik diminta untuk menceritakan pengalaman yang menarik menurutnya tetapi masih banyak yang belum mampu bercerita dengan baik. Kegiatan pembelajaran bercerita menggunakan media wayang kardus (posttest) berlangsung dengan cara pendidik mengawali bercerita fabel (hewan) tentang hidup rukun menggunakan media wayang kardus sebagai pemicu bagi peserta didik, pembelajaran bercerita berjalan dengan efektif karena peserta didik terlihat tertarik medengarkan cerita yang disampaikan oleh pendidik, kemudian setelah itu guru meminta peserta didik untuk maju menceritakan kembali isi cerita yang sudah disampaikan dengan menggunakan media wayang kardus. Menghadirkan media berupa wayang berbentuk hewan-hewan dari kardus cukup menarik perhatian dan minat peserta didik, pada saat kegiatan pemelajaran bercerita berlangsung peserta didik terlihat lebih semangat. Pada umumnya peserta didik sudah mampu memahami pesan yang terdapat pada media wayang kardus tersebut, sehingga mereka lebih mampu menguasai alur dan isi cerita yang disampaikan (Sari, 2017). Penggunaan media wayang kardus dalam pembelajaran bercerita membantu peserta didik dalam memahami isi cerita, hal ini membuat nilai perolehan peserta didik menjadi meningkat (Yanti, 2019). Hasil penelitian menggunakan uji-t (one sampet test) menunjukkan bahwa diketahui nilai signifikansi sebesar 0,000 lebih kecil dari signifikansi 0,05 $(0,000<$ $0,05)$, maka hipotesis $\left(H_{1}\right)$ dalam penelitian ini dinyatakan diterima. Artinya, bahwa variabel penggunaan media wayang kardus berpengaruh terhadap kemampuan bercerita peserta didik, terdapat pengaruh yang signifikan antara kemampuan bercerita peserta didik sebelum menggunakan media dengan sesudah menggunakan media wayang kardus pada peserta didik kelas II di UPT SDN 106. 
3201 Pengaruh Penggunaan Media Wayang Kardus terhadap Kemampuan Bercerita Peserta Didik di Sekolah Dasar - Islahatul Muthohharoh, Syamsul Ghufron, Nafiah, Sri Hartatik

DOI: https://doi.org/10.31004/basicedu.v5i5.1267

\section{KESIMPULAN}

Berdasarkan penyajian hasil penelitian dan pembahasan disimpulkan bahwa:

Hasil dari kemampuan bercerita peserta didik sebelum menggunakan media wayang kardus pada kelas II UPT SDN 106 Gresik secara umum dikategorikan masih kurang mampu. Hal ini dibuktikan dengan nilai peserta didik yang belum mencapai KKM (70) sebanyak 10 siswa (45.5\%) dan yang sudah mampu mencapai KKM (70) sebanyak 12 siswa (54.5\%). Nilai rata-rata yang diperoleh peserta didik adalah 67.82.

Kemampuan bercerita peserta didik setelah menggunakan media wayang kardus pada kelas II UPT SDN 106 Gresik menunjukkan sebuah peningkatan kemampuan bercerita secara umum dikategorikan sangat mampu. Hal ini dibuktikan dengan nilai peserta didik yang mampu mencapai KKM (70) sebanyak 21 siswa $(95,5 \%)$ dan peserta didik yang belum mampu mencapai KKM (70) hanyak ada 1 siswa (4,5\%). Nilai rata-rata yang diperoleh peserta didik adalah 83,59.

Ada pengaruh media wayang kardus terhadap kemampuan bercerita peserta didik kelas II di UPT SDN 106 Gresik menunjukkan bahwa nilai signifikansi sebesar 0,000 lebih kecil dari signifikansi $0,05(0,000<$ 0,05), maka hipotesis $\left(H_{1}\right)$ dalam penelitian ini dinyatakan diterima. Artinya, bahwa variabel penggunaan media wayang kardus berpengaruh terhadap kemampuan bercerita peserta didik kelas II UPT SDN 106 Gresik.

\section{DAFTAR PUSTAKA}

Annafiah, L. (2017). Implementasi Metode Bercerita Dengan Menggunakan Media Boneka Untuk Meningkatkan Kemampuan Bercerita Anak Usia Dini Kelompok A Di Tk Masyithoh V Kemloko Bantul Yogyakarta.

Asrul, Rusydi Ananda, R. (2014). Evaluasi Pembelajaran.

Cokorda Istri Ratih Komala Dewi, I Komang Ngurah Wiyasa, N. W. S. (2018). Penerapan Metode Bercerita Menggunakan Media Wayang Flanel Untuk Meningkatkan Kemampuan Bercerita Pada Anak.

Darmadi, H. (2011). Metode Penelitian Pendidikan. Bandung: Alfabeta.

Fatria \& Husna. (2019). Jurnal Pendidikan Bahasa Dan Sastra Indonesia. 3(2), 67-72.

Irfan. (2017). Pengaruh Penggunaan Media Gambar Terhadap Kemampuan Bercerita Dalam Bahasa Bugis Siswa Kelas Viii Smp Negeri 4 Sinjai Timur.

Ismiulya, F. (2019). Penerapan Metode Bercerita Menggunakan Media Wayang Kardus Untuk Meningkatkan Pemahaman Konsep Huruf Pada Anak Usia 5-6 Tahun Di Tkit Cendekia Darussalam Aceh Besar.

Khair, U. (2018). Pembelajaran Bahasa Indonesia Dan Sastra ( Basastra ) Di Sd Dan Mi. 2(1).

Laila Nur Amalia, Prihatin Sulistyowati, I. L. (2020). Pengaruh Model Pembelajaran Problem Based Learning (Pbl) Berbantuan Media Wayang Kardus Terhadap Keterampilan Berpikir Kritis Siswa Pada Materi Kegiatan Ekonomi Kelas Iv Sd. 4, 472-480.

Lauroza, S. P., \& Hartati, S. (2019). Pengaruh Media Gambar Terhadap Kemampuan Bercerita Anak Di Tk Islam Daud Kholifahtulloh Tabing Padang Influence Of Image Media On Children'S Storytelling Abililities In Tk Islam Daud Kholifatulloh Tabing. 6(1).

Rachmi, T. (2015). Pengaruh Permainan Dan Kemampuan Menyimak Terhadap Kemampuan Bercerita.

Ramli, M. (2018). Media Dan Teknologi Pembelajaran.Banjarmasin:Iain Antasari Press.

Rukayah, 2015. (2015). Mengembangkan Kemampuan Berbicara Menggunakan Media Wayang Kardus Di Kelompok A Tk Pertiwi Desa Patihan Kecamatan Loceret Kabupaten Nganjuk Tahun Ajaran 2014-2015. $1-14$.

Sanura, A. P. (2018). Penggunaan Media Kartu Bergambar Untuk Mengembangkan Kemampuan Bercerita 
3202 Pengaruh Penggunaan Media Wayang Kardus terhadap Kemampuan Bercerita Peserta Didik di Sekolah Dasar - Islahatul Muthohharoh, Syamsul Ghufron, Nafiah, Sri Hartatik

DOI: https://doi.org/10.31004/basicedu.v5i5.1267

Anak Usia Dini Di Ra Takrimah Tungkob Aceh Besar.

Sari, N. R. (2017). Pengaruh Media Wayang Kardus Terhadap Hasil Belajar Mengidentifikasi Unsur Cerita Siswa Kelas V Sdn Pandeanlamper 03 Semarang. 1092-1106.

Sri Joeda Andajani, M. S. (2008). Efektivitas Penggunaan Media Wayang Koran Dalam Pembelajaran Keterampilan Bercerita Anak Kelompok B.

Subekti, W. E. (2016). Penggunaan Metode Bercerita Dengan Media Wayang Perca Untuk Meningkatkan Pengetahuan Moral Anak Kelompok B3 Di Tk Pkk Sendangagung Minggir Sleman.

Suciati, S., \& Fatimah, S. (2018). Wayang Kardus Sebagai Media Pembelajaran Mengonversi Naskah Drama Untuk Smp. 3, 34-44.

Sugiyono. (2018). Metode Penelitian Kuantitatif.

Sukmadinanta, N. S. (2012). Metode Penelitan Pendidikan.

Thirsa Laules Purwa, H. (2019). Pengaruh Media Wayang Kertas Siswa Kelas Iv Sdn Di Kecamatan Modo Lamongan. 2811-2820.

Wijayak, S., \& Wismanto, A. (2020). Penerapan Media Wayang Kardus Anekdot Peserta Didik Kelas X Sma Muhammadiyah Tawangharjo Tahun Pelajaran 2019/2020. Ii(2).

Yanti, I. (2019). Penerapan Metode Bercerita Dan Media Wayang Kardus Untuk Meningkatkan Motivasi Belajar Dalam Pembelajaran Aqidah Akhlak Pada Siswa Kelas Iv Madrasah Ibtidaiyah Nurul Ittihad. 